\title{
HEPATOPROTECTIVE EFFECTS OF POLYHERBAL FORMULATION AGAINST CARBON TETRACHLORIDE-INDUCED HEPATIC INJURY IN ALBINO RATS: A TOXICITY SCREENING APPROACH
}

\author{
BHUMIKA YOGI ${ }^{1 *}$, ASHUTOSH MISHRA ${ }^{2}$ \\ ${ }^{1}$ Department of Pharmaceutical Chemistry, Hygia Institute of Pharmaceutical Education and Research, Lucknow, Uttar Pradesh, India. \\ ${ }^{2}$ Department of Pharmaceutical Chemistry, Acharya Narendra Deo College of Pharmacy, Babhnan, Gonda - 271 313, Uttar Pradesh, India. \\ Email: bhumi.is.yogi@gmail.com
}

Received: 18 August 2016, Revised and Accepted: 23 November 2016

ABSTRACT

Objective: To investigate the hepatoprotective activity of aqueous methanolic extract of polyherbal formulation and individual extracts of Calotropis procera, Gymnema sylvestre, and Lawsonia inermis leaves.

Methods: The hepatoprotective activity of the formulation and extracts were assessed on the basis of histopathological changes in liver of carbon tetrachloride-induced hepatotoxic rats.

Results: The result of present studies strongly indicates that the hepatoprotective property of polyherbal formulation as evidenced by less damaged hepatocytes cells.

Conclusion: Polyherbal formulation revealed excellent hepatoprotective profile as compared to individual plants due to synergistic effect produced by different phytochemicals present in the formulation.

Keywords: Calotropis procera, Gymnema sylvestre, Lawsonia inermis, Carbon tetrachloride.

(c) 2017 The Authors. Published by Innovare Academic Sciences Pvt Ltd. This is an open access article under the CC BY license (http://creativecommons. org/licenses/by/4. 0/) DOI: http://dx.doi.org/10.22159/ajpcr.2017.v10i1.14757

\section{INTRODUCTION}

Liver diseases have turned into a global concern worldwide. The primary causative variable is increasing alcohol consumption, anemia, disease, malnutrition, iron deficiency, and accessibility of hepatotoxic medications over the counter. Treatment choices for normal liver diseases, for example, cirrhosis, chronic hepatitis, and fatty liver are dangerous. The routine medications utilized as a part of the treatment of liver illnesses, viz., corticosteroids, antiviral, and immunosuppressant drugs are once in a while deficient and may prompt genuine antagonistic impacts. Incomprehensibly, these may themselves bring about hepatic harm [1].

Calotropis procera (Ait) R.Br. belongs to family Asclepiadaceae, locally known as "Madar" [2]. C. procera is one of the most popular medicinal herbs in India [3]. Different parts of the plant have been used as anthelmintic, purgative and in diseases such as ulcer and leprosy. The latex of this plant possess antidiarheal [4], antidiabetic [5], anticancer properties [6], and antipyretic analgesic [7]. The root extract is reported to have antitumor [8], anti-inflammatory, and analgesic effects [9]. The stem bark possesses antifungal property [10]. In view of these observations, the $C$. procera has established a good deal of interest from pharmacological interest.

Gymnema sylvestre R. Br. belongs to the family Asclepiadaceae [11]. In India, it is known as "gur-mar" or "sugar destroyer" because the leaves of this plant have antidiabetic activity [12]. It is used in folk, Ayurvedic, and Homeopathic Systems of Medicine. G. sylvestre leaves have gymnemic acids, which is important in balancing insulin levels and lowering blood sugar [13]. It is reported to possess antihypercholesterolemic, antimicrobial, antiallergic, hepatoprotective, antiviral [14], hypoglycemic, hypolipidemic [15] diuretic [16], and anticancerproperties [17].
Lawsonia inermis Linn. is commonly known as "henna." This plant has been used for the treatment of epilepsy and for malignant ulcer. Henna reduced both hyperglycemia and inflammation significantly [18]. Moreover, the leaves are used as hepatoprotective, antioxidant, bronchitis, headache, ophthalmia, syphilitics, amenorrhea, scabies, and also in hair growth [19-25].

In third world countries including India, up to $90 \%$ of the populace still relies entirely on plants as a resource of medicines [26]. Due to lack of a consistent liver protective medicine in the modern system, a number of medicinal preparations in Ayurveda, the Indian system of medicine, are recommended for the cure of liver disorders. Natural remedies from medicinal plants are considered to be effective and safe option medicines for hepatotoxicity. Carbon tetrachloride $\left(\mathrm{CCl}_{4}\right)$-induced hepatic injury is one of the most investigated animal models and in the past decades, molecular mechanisms for hepatic necrosis, and steatosis induced by $\mathrm{CCl}_{4}$ were well prominent. It is assumed that the effect of G. sylvestre, C. procera, and L. inermis extracts on liver protection is related to free radical suppressing activity. This study deals with the comparison of hepatoprotective activity of herbal formulation against individual extracts. Therefore, in this try out, we report the comparative hepatoprotective effects of formulation and individual extracts against $\mathrm{CCl}_{4}$-induced hepatic injury.

\section{METHODS}

Collection and authentication of plant materials

The leaves of $C$. procera, G. sylvestre, and L. inermis were collected from Herbal Garden of Hygia Institute of Pharmaceutical Education and Research, Lucknow, Uttar Pradesh, India, in the month of January and February and identified at the NISCAIR Delhi and CIMAP, Lucknow. Voucher specimens (1144/176, GS-1, LI-1) has been deposited for further future reference. 
Preparation of crude extracts and polyherbal formulation

Fresh leaves of C. procera, G. sylvestre, and L.inermis were collected, cleaned and dried under shade. Herbal ingredients were powdered separately and stored. Polyherbal preparation was made by mixing the three ingredients in equal ratio $(\mathrm{w} / \mathrm{w})$ and homogenizing in aqueous methanol (30:70) with the help of a pestle and mortar [27]. Polyherbal formulation and crude extracts were macerated with aqueous methanol (30:70) for 7 days in airtight vessels with occasional shaking at room temperature. Then filtration was done with Whatman filter paper No. 1. The filtrates were concentrated under reduced pressure in rotary evaporator. The formulation and crude extracts were stored in airtight container.

\section{Phytochemical studies}

All extracts were subjected for phytochemical psychoanalysis to determine the presence of alkaloids, glycosides, saponins, steroids, proteins, polysaccharides, and tannins [28].

\section{Evaluation of hepatoprotective activity \\ Experiment animals}

Albino Wistar rats were used in this study. The project was approved by the Institution Animal Ethical Committee (1088/PO/Re/S/2007/ CPCSEA). The animals were kept at $27 \pm 2^{\circ} \mathrm{C}$ with relative humidity $44-46 \%$ and light and dark cycles of 10 and $14 \mathrm{hrs}$, respectively, for 1 week before and during experiments. Animals were provided with standard diet (Lipton, India) and water ad libitium. Food was withdrawn 18-24 hrs before the start of the experiment. All the experiments were performed in the morning according to current course of action for the care of the Laboratory Animals and the Ethics Guidelines.

\section{Acute toxicity studies}

The acute toxicity studies for the formulation and extracts of G. sylvestre, C. procera, and $L$. inermis were performed earlier using OECD 423 guideline [27].

\section{Screening method}

Rats were divided into seven groups of six animal each $(n=6)$. Group I (control) animals were administered a single dose of water ( $1 \mathrm{ml} / \mathrm{kg}$, p.o.) daily for 5 days and received liquid paraffin $(1: 1,2 \mathrm{ml} / \mathrm{kg}$, s.c.) on day 2 and 3. Group II $\left(\mathrm{CCl}_{4}\right)$ received water $(1 \mathrm{ml} / \mathrm{kg}$ body weight, p.o.) once daily for 5 days and received $\mathrm{CCl}_{4}$ :liquid paraffin $(1: 1,2 \mathrm{ml} / \mathrm{kg}$ body weight, s.c.) on day 2 and 3. Group III received standard drug silymarin (100 mg/kg, p.o.) once daily for 5 days. Test groups animals (Groups IV-VII) were administered orally a dose of $200 \mathrm{mg} / \mathrm{kg}$ of polyherbal formulation, G. sylvestre, C. procera, and L. inermis extracts, respectively, in the form of aqueous suspension once daily. The Groups III-VII animals were administered in tandem $\mathrm{CCl}_{4}$ :liquid paraffin (1:1, $2 \mathrm{ml} / \mathrm{kg}$ body weight, s.c.) on day 2 and 3 after $30 \mathrm{~min}$ of administration of the silymarin and extracts [29].

\section{Estimation of biochemical markers}

Biochemical parameters such as serum glutamic oxaloacetic transaminase (SGOT), serum glutamic pyruvic transaminase (SGPT), serum alkaline phosphatase (ALP), and total bilirubin, cholesterol were analyzed and reported previously [27].

\section{Histopathological studies}

The animals from all the groups were sacrificed using euthanasia $24 \mathrm{hrs}$ after $\mathrm{CCl}_{4}$ administration. The liver was dissected out and used for histopathological studies [30]. Briefly liver was sliced and pieces were preserved in $10 \%$ formalin for proper fixation. These tissues were processed and embedded in paraffin wax. Section of 5-6 $\mu$ in thickness was cut and stained with hematoxylin and eosin. All the sections of the tissues were examined under microscope for analyzing the altered architecture in the liver tissue due to $\mathrm{CCl}_{4}$ challenge and improved liver architecture due to pretreatment with test extracts and standard drug which was documented by taking images using microscope.

\section{Histopathological findings}

The severity of the liver morphological changes induced by $\mathrm{CCl}_{4}$ treatment was summarized. Our results showed that administration of silymarin greatly improved liver morphological changes, fibrosis, and necrosis. The liver sections of the rats from control group had normal hepatic cells with well-preserved cytoplasm, central vein, and prominent nucleolus (Fig. 1a). Severe histopathological changes
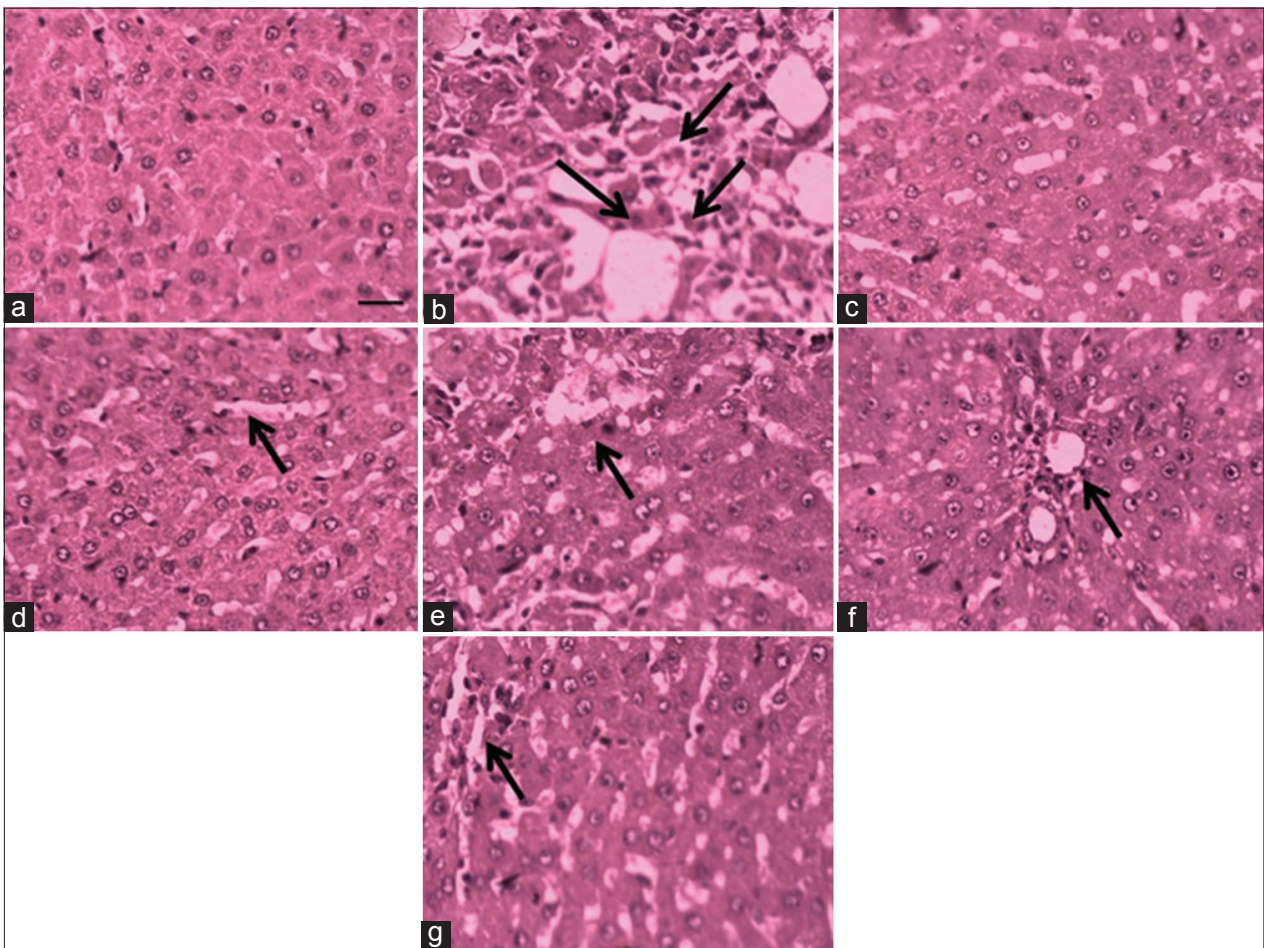

Fig. 1: Sections stained with hematoxylin and eosin $(\times 400)$ displaying the liver sections of rats treated with, (a) Control group,

(b) carbon tetrachloride (CCl4) group, (c) standard group, (d) polyherbal formulation, (e) Gymnema sylvestre, (f) Calotropis procera, and (g) Lawsonia inermis is in CCl4-induced liver damage in rats 
were observed in livers of all the rats from $\mathrm{CCl}_{4}$-treated animals. In $\mathrm{CCl}_{4}$ treated animals, the sections showed sever degree of liver damage, such as necrosis, hydropic degeneration, and infiltration of inflammatory cells (Fig. 1b). The histological appearance of the silymarin group was quite similar to that of the control group (Fig. 1c). In polyherbal formulation $(200 \mathrm{mg} / \mathrm{kg}$, p.o.) treated animals, liver section showing clearly less than those groups that received $\mathrm{CCl}_{4}$ only. The livers of the rats in this group showed occasional dysplastic hepatocytes and apoptotic cells, most of which were not abnormal and no extensive necrotic, and hydropic degeneration changes were seen in livers (Fig. 1d). In G. sylvestre (200 mg/kg, p.o.) treated animals, the liver sections showed mild inflammation, but overall picture resembles normal liver (Fig. 1e).

Treatment with C. procera (200 $\mathrm{mg} / \mathrm{kg}$, p.o.) showed moderate inflammation and congestion, however, only a few lobules of livers showed a focus of degenerative cells, most of which had the normal nuclear appearance and mild cytoplasmic degeneration (Fig. 1f). Treatment with $L$. inermis $(200 \mathrm{mg} / \mathrm{kg}$, p.o.) showed moderate inflammation and congestion (Fig. 1g). Morphological findings in all groups of this study were consistent with observations of serum enzymes such as SGPT, SGOT, ALP, cholesterol, and tuberculosis values as reported previously [27].

\section{RESULTS AND DISCUSSION}

The liver can be injured by various chemicals and drugs. In this study, $\mathrm{CCl}_{4}$ was selected as a hepatotoxicant to induced liver damage. The primary goal of this study is to assess the comparison studies of hepatoprotective activity between herbal formulation and individual extract of various plants against chronic liver damage. Histopathological changes such as sever macrovesicular, congestion, and microvesicular steatosis were observed in $\mathrm{CCl}_{4}$ treated groups. All extracts prevented these histopathological changes, further indicating their hepatoprotective activity.

From the results, the hepatoprotective activity of the extracts were in the order of Group III received standard drug silymarin (100 mg/kg, p.o.) > Groups IV received polyherbal formulation extracts ( $200 \mathrm{mg} / \mathrm{kg}$, p.o.) > Groups V received G. sylvestre extracts (200 mg/kg, p.o.) > Groups VI received C. procera extracts (200 mg/kg, p.o.) > Groups VII received L. inermis extracts $(200 \mathrm{mg} / \mathrm{kg}$, p.o.). Phytoconstituents such as phenolic compounds and tannins were reported for their hepatoprotective effects [27] and these two were present in alcoholic and aqueous extracts. These active principles may be accounted for hepatoprotective effect. In summary, this study demonstrates that polyherbal formulation had a protective effect against $\mathrm{CCl}_{4}$-induced acute hepatic damage in rats. The hepatoprotective effect of polyherbal formulation is expected due to its ability to the inflammatory responses, in combination with the ability to scavenge free radicals.

\section{CONCLUSION}

The result of this study clearly demonstrates that the histopathological alterations produced by $\mathrm{CCl}_{4}$ in tissue were significantly reserved by the pretreatment of extracts of polyherbal formulation, crude extracts, and Silymarin. In conclusion, the polyherbal formulation showed good hepatoprotective effect as compared to the individual extracts against $\mathrm{CCl}_{4}$-induced hepatotoxicity in albino rats. This study confirms its use as hepatoprotective as per the ethno pharmacological claims.

\section{ACKNOWLEDGMENT}

The authors are grateful to the Management and Mr. Sujeet Kumar Gupta for providing necessary laboratory facilities of Hygia Institute of Pharmaceutical Education and Research Lucknow.

\section{REFERENCES}

1. Petri WA. Antimicrobial agents. In: Gilman AG, Hardman JG, Limbird LE, editors. The Pharmacological Basis of Therapeutics. $10^{\text {th }}$ ed. New York: McGraw-Hill Publication Corporation; 2001. p. 1189-93.

2. Mossa JS, Tariq M, Mohsin A, Ageel AM, Al-Yahya MA, Al-Said MS, et al. Pharmacological studies on aerial parts of Calotropis procera. Am J Chin Med 1991;19(3-4):223-31.

3. Yogi B, Murti Y, Pathak D. Pharmacognostical standardization of leaves of Calotropis procera (Ait) R. Br. (Asclepiadaceae). Int J Ayurveda Res 2010;1(1):14-7.

4. Kumar S, Dewan S, Sangraula H, Kumar VL. Anti-diarrhoeal activity of the latex of Calotropis procera. J Ethnopharmacol 2001;76(1):115-8.

5. Roy S, Sehgal R, Padhy BM, Kumar VL. Antioxidant and protective effect of latex of Calotropis procera against alloxan-induced diabetes in rats. J Ethnopharmacol 2005;102(3):470-3.

6. Choedon T, Mathan G, Arya S, Kumar VL, Kumar V. Anticancer and cytotoxic properties of the latex of Calotropis procera in a transgenic mouse model of hepatocellular carcinoma. World J Gastroenterol 2006;12:2517-22.

7. Dewan S, Sangraula H, Kumar VL. Preliminary studies on the analgesic activity of latex of Calotropris procera. J Ethnopharmacol 2000;73(1-2):307-11

8. Mathur R, Gupta SK, Mathur SR, Velpandian T. Anti-tumor studies with extracts of Calotropis procera (Ait.) R.Br. root employing Hep2 cells and their possible mechanism of action. Indian J Exp Biol 2009; 47:343-8.

9. Basu A, Chaudhuri AK. Preliminary studies on the antiinflammatory and analgesic activities of Calotropis procera root extract. J Ethnopharmacol 1991;31(3):319-24.

10. Kuta F. Antigungal effect of Calotropis procera stem bark on epidermophytonosum and trichophtongypseum. Afr J Biotechnol 2008;7(13):2116-8.

11. Ahirwa L, Singh S. Screening of methanolic extract of Gymnema sylvestre R. Br. Leaves for antioxidant potential. Int J Pharm Sci Rev Res 2013;19(1):87-91.

12. Liu HM, Kiuchi F, Tsuda Y. Isolation and structure elucidation of gymnemic acids, antisweet principles of Gymnema sylvestre. Chem Pharm Bull (Tokyo) 1992;40(6):1366-75.

13. Najafi S, Deokule SS. Studies on Gymnema sylvestre - A medicinally important plant of the family Asclepiadaceae. Trakia J Sci 2011;9:26-32.

14. Kanetkar P, Singhal R, Kamat M. Gymnema sylvestre: A memoir. J Clin Biochem Nutr 2007;41(2):77-81.

15. Daisy P, Eliza J, Mohamed Farook KA. A novel dihydroxy gymnemic triacetate isolated from Gymnema sylvestre possessing normoglycemic and hypolipidemic activity on STZ-induced diabetic rats. J Ethnopharmacol 2009;126(2):339-44.

16. Reddy S, Gopal G, Sit G. In vitro multiplication of Gymnema sylvestre $R$ Br: An important medicinal plant. Curr Sci 2004;10:1-4.

17. Khanna GV, Kannabiran K. Anticancer-cytotoxic activity of saponins isolated from the leaves of Gymnema sylvestre and Eclipta prostrata on HeLa cells. Int J Green Pharm 2009;3(3):227-9.

18. Imam H, Mahbub NU, Khan MF, Hana HK, Sarker MM. Alpha amylase enzyme inhibitory and anti-inflammatory effect of Lawsonia inermis. Pak J Biol Sci 2013;16(23):1796-800.

19. Devendra KB, Tiravenkata RS, Singh R. Xanthones from Lawsonia inermis. Phytochemistry 1977;16:1616-7.

20. Aiferah MA. Toxicity induced histological changes in selected organs of male (wistar) rats by Lawsonia inermis leaf extract. Eur J Med Plants 2012;2(2):151-8.

21. Mikhaeil BR, Badria FA, Maatooq GT, Amer MM. Antioxidant and immunomodulatory constituents of henna leaves. Z Natureforschung C 2004;59(7-8):466-8.

22. Hsouna AB, Trigui M, Culioli G, Blache Y, Jaoua S. Antioxidant constituents from Lawsonia inermis leaves: Isolation, structure and antioxidative capacity. Food Chem 2011;125:193-200.

23. Kirkland D, Marzin D. An assessment of the genotoxicity of 2-hydroxy1,4-naphthoquinone, the natural dye ingredient of Henna. Mutat Res 2003:537:183-99.

24. Thabrew MI, Joice PD, Rajatissa W. A comparative study of the efficacy of Pavetta indica and Osbeckia octandra in the treatment of liver dysfunction. Planta Med 1987;53(3):239-41.

25. Constantin M, Bromont C, Fickat R, Massingham R. Studies on the activity of bepridil as a scavenger of free radicals. Biochem Pharmacol 1990;40(7):1615-22.

26. Bello IA, Ndukwe GI, Audu OT, Habila JD. A bioactive flavonoid from Pavetta crassipes K. Schum. Org Med Chem Lett 2011;1:14.

27. Yogi B, Mishra A. Hepatoprotective effects and antioxidant potential of polyherbal formulation against $\mathrm{CCl}_{4}$-induced hepatic injury in albino rats. Curr Tradit Med 2016;2:42-9. 
28. Harborne JB. Phytochemical Methods. Vol. 3. London: Chapman \& Hall; 1988. p. 117-9.

29. Jain A, Soni M, Deb L, Jain A, Rout SP, Gupta VB, et al. Antioxidant and hepatoprotective activity of ethanolic and aqueous extracts of
Momordica dioica Roxb. leaves. J Ethnopharmacol 2008;115:61-6.

30. Shammugasundaram P. Hepatoprotective and antioxidant activity of Hygrophila auriculata heine Acanthaceac root extract. J Ethanopharmacol 2006;104:124-8. 